\title{
CORRECTIONS
}

\section{Publisher Correction: A call for a better understanding of causation in cell biology}

Mariano Bizzarri, Douglas E. Brash, James Briscoe, Verônica A. Grieneisen, Claudio D. Stern and Michael Levin (D)

Nature Reviews Molecular Cell Biology (2019) https://doi.org/10.1038/s41580-019-0127-1

Published online 8 April 2019

In the above article, the name of the first author was spelled incorrectly. This has been corrected in the HTML and PDF versions of the article.

https://doi.org/10.1038/s41580-019-0130-6 I Published online 18 April 2019

\section{Publisher Correction: Quality and quantity control of gene expression by nonsense-mediated mRNA decay}

Tatsuaki Kurosaki iD, Maximilian W. Popp and Lynne E. Maquat

Nature Reviews Molecular Cell Biology (2019) https://doi.org/10.1038/s41580-019-0126-2

Published online 16 April 2019

The HTML version of the article displayed the wrong Figure 3 (while the PDF version was correct); the HTML has now been corrected and we apologize for any confusion it may have created.

https://doi.org/10.1038/s41580-019-0138-y I Published online 26 April 2019 